\title{
"VIRTUAALINEN KIEKKOJUMALA" Jeremy Roenick, NHL 94 ja samastuminen urheilupeleissä
}

Elokuvassa Swingers (Doug Liman, 1996) kaksi pari-kolmekymppistä miestä pelaa pelikonsolilla jääkiekkopeliä. ${ }^{1}$ Kiihkeän kamppailun ohessa he kommentoivat peliä. Vince Vaughnin esittämä hahmo kysyy NHL-seura Los Angeles Kingsin pelipaitaan pukeutuneelta kaveriltaan (Patrick Van Horn), miksi tämä pelaa Kingseillä, vaikka "he ovat tässä pelissä niin surkeita", tehden implisiittisen eron oikeaan Kingsiin. ${ }^{2}$ Kaveri on eri mieltä ja kertoo vieneensä Kingsit mestaruuteen. Vaughnin hahmo tuhahtaa ivallisesti saavutuksen kyseenalaistaen: "Niin, [tietysti] tietokonetta vastaan ja paitsiosääntö pois päältä!"3 ("Swingers (1996) Hockey Clip" 2006.)

Hän jatkaa: "Kyse ei ole niinkään siitä, että minä olen hyvä vaan Roenickista. Hän on hyvä!" Ruudulla hänen ohjaamansa "Roenick" pyörii kiekon kanssa aikansa vastustajan päädyssä, pyörähtää kulmasta pois ja tekee maalin. Kuvaruudulla maalin tehneen joukkueen, Chicago Blackhawksin, pelaajat tuulettavat ja tulosruudulla lukee: "Goal! 27 J. Roenick. Assist by: 28 S. Larmer". Tämän jälkeen Vaughnin hahmo keskittyy taklaamaan "Gretzkyn" niin, että tämän "päästä tulee verta", missä hän pienellä huijauksella onnistuukin: pian "Gretzky" makaa jäällä verta vuotaen. Kings-fani menettää malttinsa ja käy hänen idolinsa virtuaalisesti teloneen kaverinsa kimppuun.

Kohtauksessa tiivistyvät tämän artikkelin aihe, eli videourheilupelaaminen ja siihen liittyvä samastumisen problematiikka, johon Vaughnin hahmo viittaa nostamalla pelihahmon tärkeämmäksi kuin omat taitonsa pelissä menestymiselle. Tutkimusten mukaan urheilupelaamisessa yhdistyvät muun muassa lajitiedon soveltaminen, lajiin samastuminen, fantasia, kilpailullisuus ja pelaamisen sosiaalisuus. Pelaajien on katsottu identifioituvan peleissä mallinnettuihin todellisiin pelaajiin ja joukkueisiin. (Ks. esim. Kim \& Roos 2006.)

Swingers on varmasti Pohjois-Amerikan ulkopuolella tuntematon elokuva, eikä se esimerkiksi koskaan ollut teatterilevityksessä Suomessa. Pohjois-Amerikassa se

\footnotetext{
${ }^{1}$ Artikkeli on osa Emil Aaltosen säätiön rahoittamaa tutkimustani "Kaupallisen populaarikulttuurin tuotteistaminen, brändäys ja markkinointi”.

2 "They suck in this game!" [kurs. R.M.] NHL 94 perustui kaudelle 1992-1993. Los Angeles menestyi erinomaisesti ja pääsi Stanley Cupin finaaleihin, jossa se hävisi mestaruustaiston Montreal Canadiensille. Vaughnin hahmon kommentti ei siis koske oikeaa Kingsiä.

3 Tekoälyä pidetään helpompana vastustajana kuin (taitavaa) inmisvastustajaa; paitsiosäännön kytkeminen pois päältä voi auttaa pelaajaa, mutta toisaalta myös vastustajaa. Joka tapauksessa sen tai muiden jääkiekon sääntöjen kytkemistä pois päältä pidetään hyvin arveluttavana jääkiekkopelien harrastajien keskuudessa.
} 
on taas kulttielokuva, mikä johtunee nimenomaan kuvatusta kohtauksesta. Kohtaus taltioi tuoreeltaan yhden tunnetuimmista urheilupelilegendoista, eli NHL-tähti Jeremy Roenickin (s. 1970) pelihahmon ylivertaisuuden EA Sports -yhtiön NHL 94 -jääkiekkovideopelissä. Johnson (2013) kirjoittaa, miten NHL-pelissä Roenick mallinnettiin hänen ominaisuuksiensa perusteella, mutta tapahtui jotain odottamatonta: "digitaalisesta Roenickista tuli 'kiekkojumala"' (the god of hockey). Käyttäisin itse digitaalisen sijaan termiä virtuaalinen, mistä tämän artikkelin otsikko. Tapaus avaa hedelmällisen näkökulman urheilupelaamiseen niin Suomessa kuin kansainvälisesti. NHL on Suomen suosituin urheilupeli vuodesta toiseen (Kinnunen et al. 2018; Qaund et al. 2014, 34-35). Artikkelissa nostan yhtäältä esiin niitä tekijöitä, joilla NHL-pelisarjasta aikanaan rakennettiin menestystarina. Toisaalta katson, miten tämä näkyy käyttäjäkommenteissa, mikä johtuu epäilemättä ensi sijassa jääkiekon yleisösuosiosta, vaikka pelejä pidettäisiinkin "vain" onnistuneina peleinä.

\section{NHL 94 urheilupelinä}

EA Sportsin NHL 94 on konsolipeli, jota pidetään yleisesti yhtenä kaikkien aikojen niin jääkiekko- kuin ylipäätään urheiluvideopeleistä (ks. esim. Johnson 2013; Classic Gaming Quarterly 2016). Se on yksi osa vuosittain uutena, päivitettynä editiona ilmestyvää pelisarjaa, jonka uusin laitos on $\mathrm{NHL} 20 .{ }^{4}$ Ensimmäinen sarjan peli, $N H L$ Hockey, julkaistiin vuonna 1991. Sen esikuvana oli EA:n jenkkifutispeli John Madden Football ${ }^{5}$, jonka ensimmäinen versio ilmestyi vuonna 1988. NHL 94:n suosiota nosti sen aiempaa paremmaksi koettu pelattavuus sekä ennen kaikkea avainelementiksi noussut suoraan syötöstä -laukaus (one timer). Laukauksella maalintekoon tuli uusi, realistinen ulottuvuus, sillä se on myös oikean jääkiekon tehokkaimpia tapoja yrittää tehdä maali. EA Sportsin tuottaja Sean Ramjagsingh on todennut, että NHL 94 oli ensimmäinen "kerta" (so. jääkiekkopeli), jossa saattoi tehdä "mitä vain halusi, milloin vain halusi ja sait ruudulla juuri sen mitä odotit", mikä "oli suuri osa NHL 94 -kokemusta". (NHL 2013.) Vaikka lausunnosta vähentäisi markkinapuhelisän, voi todeta, että peli oli todellinen menestys ja tänä päivänä klassikko. ${ }^{6}$

NHL lisensioi sarjan ensimmäisen pelin, NHL Hockeyn (1991), jossa oli mukana kaikki sarjan joukkueet, mutta ei pelaajien nimiä, koska pelaajayhdistys ei ollut mukana. NHL myös puuttui pelin sisältöön. Kun NHL:lle selvisi, että peliin oli ohjelmoitu myös tappeleminen, se yritti estää pelin julkaisun uhkaamalla vetää lisenssinsä pois. Tämä tapahtui liian myöhään, koska peli oli jo tuotannossa. NHL kuitenkin toteutti uhkauksensa ja veti lisenssinsä pois seuraavalta versiolta. Peli ilmestyi nimellä NHLPA '93. Nimi viittaa liigan sijasta NHL:n pelaajayhdistykseen (Players' Association), mikä tarkoitti sitä, että nyt mukana olivat kaikki pelaajat, muttei NHL:n logoa ja seuroja. Joukkueet oli nimetty vain kaupunkeina (Chicago, Pittsburgh ja niin edelleen). Tappelut pysyivät pelin suosittuna sisältönä. (Classic Gaming Quarterly 2016.)

\footnotetext{
4 NHL 20 julkaistiin 20.9.2019. Pelin nimen vuosiluku on aina jääkiekkokauden päätösvuosi (tässä tapauksessa kausi 2019-2020).

5 Madden (s. 1936) oli menestynyt valmentaja, jonka nimi ja ääni päätyivät peliin. Pelillä ei ollut aluksi niin NFL-liigan kuin pelaajayhdistyksenkään (NFLPA) lisenssiä, joten joukkueet olivat anonyymeja. Sittemmin peli on mainittujen tahojen lisensioima (John Madden NFL).

6 NHL 94:n kulttiasemasta kertoo paljon se, että pelissä järjestetään nykyään vuosittain kenelle tahansa avoin maailmanmestaruusturnaus "King of 94". Se järjestetään sekä Sega- että Super Nintendo -versioina. Tänä vuonna se järjestetään 21.-22. syyskuuta Torontossa. Sen ohessa on myös "rennompi" (casual) turnaus "Duke of 94" niille, jotka haluavat vain pelata muiden pelin fanien kanssa. (King of 94 2019.)
} 


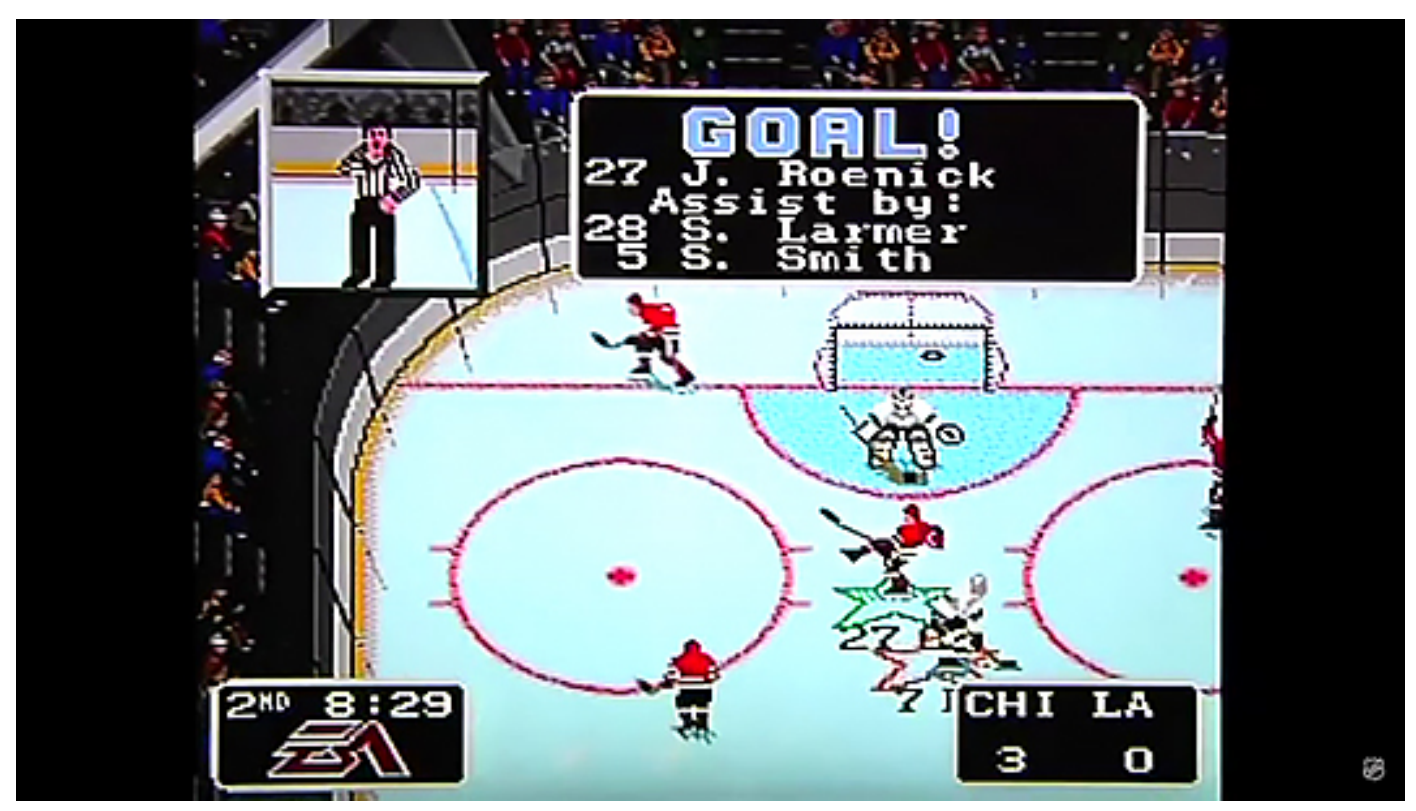

NHL 94 julkaistiin keväällä 1993. "J. Roenick" (27) tuulettaa maalia jälleen kerran. Kuva: kuvakaappaus pelistä.

Kuuluisa pelisuunnittelija Mark Lesser, joka oli suunnitellut John Madden Football -pelin, palkattiin suunnittelemaan seuraava versio, NHL 94, Sega Genesis -pelikonsolille. Hän otti tehtävän ilomielin vastaan, mutta hänellä oli yksi ongelma: hän ei tiennyt jääkiekosta juuri mitään. NHL palasi yhteistyökumppaniksi, mutta vain sillä ehdolla, että tappelut poistettaisiin, mihin EA suostui: selvästi he pitivät liigan ja sen joukkueiden kuulumista pelin sisältöön tappeluita tärkeämpänä. Tässä mentiin jopa niin pitkälle, että kunkin joukkueen kotihallissa soivat niille ominaiset urkukappaleet pelikatkojen aikana, mikä on varmasti lisännyt peliin samastumista kunkin joukkueen faneille. (Classic Gaming Quarterly 2016; ks. myös Graham 2013; Pinchevsky 2013; McCrea 2015; Satriano ja O'Leary 2018.) Tappelut palasivat parin vuoden tauon jälkeen peliin NHL 96, mutta näyttää varsin selvältä, että "oikeat" joukkueet ja pelaajat ovat pelikokemuksen ytimessä ja sitä kautta keskeinen pelisarjan yli neljännesvuosisadan kestänyttä elämää selittävä tekijä. Tähän palataan alla.

Norman (2013) kirjoittaa, että NHL 94 tuli markkinoille merkittävänä hetkenä NHL:n historiassa. Gary Bettman oli juuri aloittanut komissaarina ja johti NHL:n kunnianhimoisia laajentumissuunnitelmia. Erityisen keskeistä oli USA:n markkinoiden valtaaminen niiden taloudellisen potentiaalin takia - Kanadalle kansallispeli oli myyty jo ajat sitten. Erilaiset oheistuotteet sekä eri viihteen muotojen ja urheiluliigojen aggressiivinen ristiin markkinointi olivat markkinointistrategian ytimessä. Jopa Suomesta katsoen triviaalilta näyttävä urheilukeräilykorttiteollisuus nousi isoksi liiketoiminnaksi. Video- ja tietokonepelit istuivat tähän malliin kuin sitä varten luotuna. EA Sportsin NHL-pelit olivat NHL-tuotteen kasvun sekä seuraus että sitä rakentanut tekijä. ${ }^{7}$

NHL 94 oli siis ensimmäinen NHL-peleistä, jossa oli oikeiden pelaajien nimet, joukkueiden logot ja jokainen NHL-joukkue. Tästä syystä Swingers-elokuvassa, tai toisessa aikakauden elokuvassa, jossa nähdään NHL-videopeli, eli Häiriköissä

\footnotetext{
7 Mediateollisuuden konvergenssista ks. Jenkins 2006; Gray 2010.
} 
(Mallrats, Kevin Smith, 1995), ei nähdä NHL 94 -peliä, vaikka Swingers siihen epäsuorasti viittaakin. Lisensiointiverkosto esti tämän, ainakin taloudellisista syistä. (Graham 2013; Pinchevsky 2013.) NHL 94 on edelleen osa NHL-folklorea, mikä johtuu siitä, että sitä pelasivat lapsena nykyiset NHL-pelaajat, mutta vaikuttaa samalla siltä, että peliä on pelattu paljon sen "loogisen" elinkaaren jälkeen. NHL:n omalla YouTube-kanavalla on pelin 20-vuotisjuhlavideo vuodelta 2013, jolla silloiset (ja pääosin myös nykyiset) NHL-pelaajat muistelevat peliä.

Videolla Adam Henrique muistelee pelanneensa peliä pikkuveljensä kanssa. Henrique on syntynyt vuonna 1990, eli hän on ollut 3- tai 4-vuotias pelin ilmestyessä, mikä viittaa juuri pelin jatkuneeseen suosioon uusista versioista huolimatta - tai siihen, että juuri NHL 94 on ollut helposti saatavilla vanhempana pelinä. Suurin osa haastatelluista on kuitenkin 1980-luvulla syntyneitä, kuten maailman parhaana pelaajana vuosia pidetty Sidney Crosby (s. 1987). Scott Hartnell (s. 1982) toteaa taas, että NHL 94 oli hänen "ensimmäinen kanssakäymisensä 'NHL-pelaajien' kanssa". Hän tekee "NHL-pelaajat" sanoessaan lainausmerkkieleen, mikä viittaa eron tekemiseen pelin ja oikean jääkiekon välillä (NHL 2013), mutta samalla "Gretzkyn ja muiden" mainitseminen hämärtää oikean pelaajan ja tämän digitaalisen hahmon välistä suhdetta.

Myös yksi NHL:n suurimmista nykytähdistä, Auston Matthews, joka on juuri ilmestyneen NHL 20 -pelin kansikuvapelaaja, ${ }^{8}$ kertoo pelanneensa lapsena NHL 94:ää, vaikka hän itse asiassa syntyi 1997 ja hänen tullessaan videopeli-ikään pelisarja oli kehittynyt valtavasti. "Pidin siitä, koska se oli yksinkertainen, ja olin hyvä siinä. Tyypillisesti voitin." Hän pelaa sitä satunnaisesti edelleen kavereidensa kanssa. Jotkut häntä vanhemmat NHL-kiekkoilijat ovat muistelleet, miten peli oli silloin uusi osa jääkiekon harrastamista ja NHL:n seuraamista, jääkiekkokorttien, televisio-otteluiden ja muun ohessa. Brian Boyle (s. 1984) toteaa, että NHL 94 oli niin hieno peli, koska "tiesit, keitä pelin joukkueet ja pelaajat olivat". (Satriano ja O'Leary 2018.)

Miikka Lehtonen taas kirjoitti viime vuonna Pelaaja-lehdessä, että hänelle NHL 94 on "urheilupelien kukkulan kuningas". Sen merkitys on kuitenkin hänelle paljon laajempi, sillä kyseistä peliä "on pitkälti kiittäminen sitä, että minusta yleensäkään tuli urheiluhullua". Hän kävi yläastekavereidensa kanssa koulupäivien jälkeen pelaamassa paikallisessa pelikaupassa EA Sportsin urheilupelejä, vaikka hän itse ei "pahemmin urheilusta pitänytkään".

"NHL 94 oli täydellinen porttihuume, sillä se oli pelinä sangen yksinkertainen. Vauhdikas, aikanaan näyttävä ja helposti pelattava lätkäpeli ei toki oikeasti jääkiekkoa muistuttanut kuin vahingossa, mutta peliin pääsi mukaan helposti, vaikka ei lätkämies ollutkaan." (Lehtonen 2018.) Kaikki nämä esimerkit kertovat juuri siitä, miten NHL 94 nivoutui osaksi sekä jääkiekkokulttuuria että urheilupelikulttuuria. Peli osallistui näiden kahden eri pelikulttuurin välisen symbioottisen vuorovaikutussuhteen rakentamiseen.

\section{Jeremy Roenick: tähtijääkiekkoilija ja urheilupelilegenda}

Kuten Swingers-elokuvan kohtauksessa viitataan, NHL 94 -pelissä Chicagon tähtihyökkääjä Jeremy Roenick oli ylivertainen pelaajahahmo. Roenickista tuli pelin kautta "legenda" tavalla, jota hänen sinänsä komea peliuransa ei olisi mahdollistanut. Hän on useaan otteeseen kertonut, että peliuran jälkeen ihmiset tulevat aina

\footnotetext{
8 <https://www.nhl.com/news/ea-sports-nhl-20-cover-star-auston-matthews/c-307913954>. Linkki tarkistettu 10.11.2019.
} 


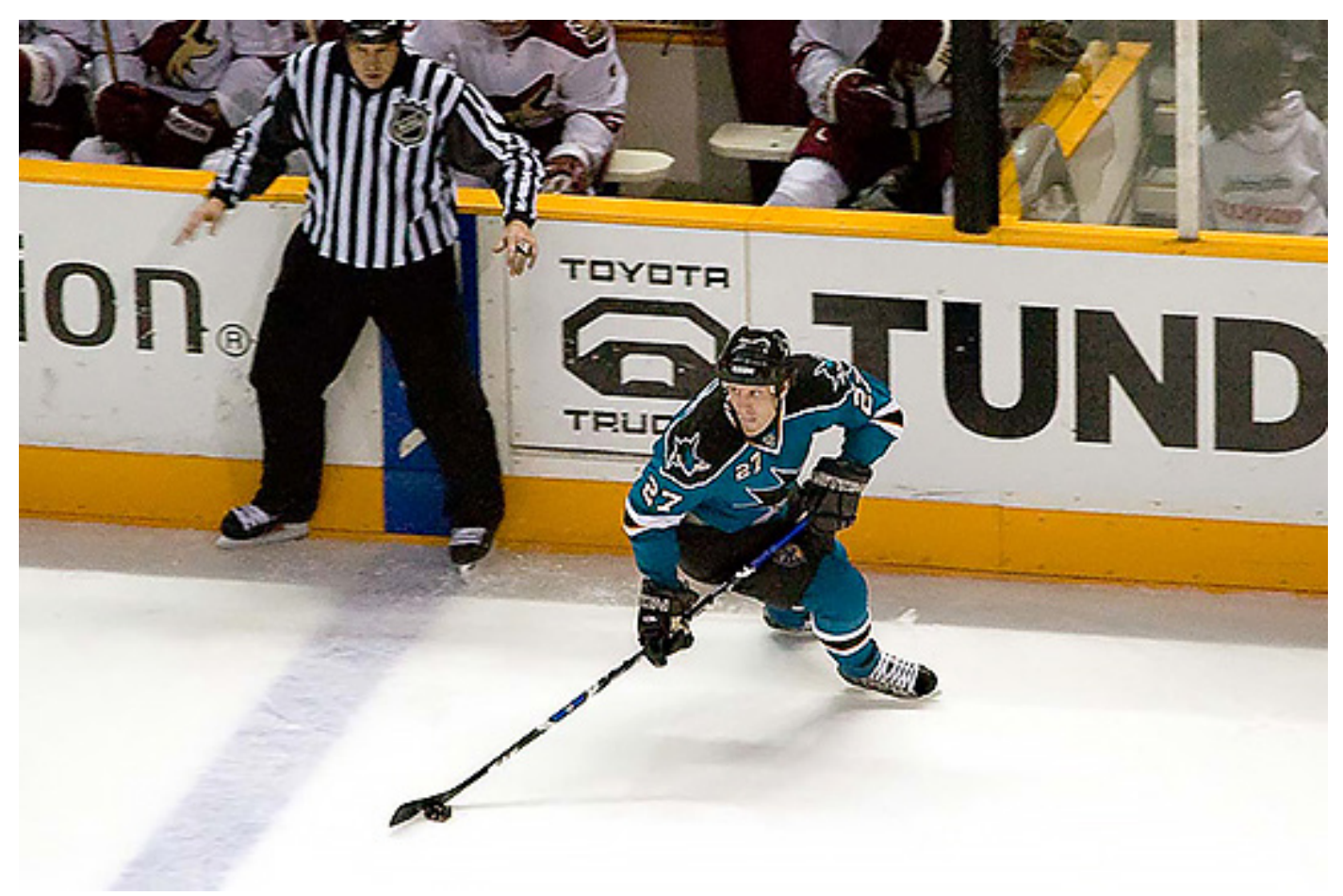

Jeremy Roenickin peliura kesti parikymmentä vuotta, 1989-2009. Hän pelasi San Jose Sharksin joukkueessa vuosina 2007-2009. Kuva: Wikimedia Commons.

puhumaan hänelle NHL 94:sta ja kuinka huippu hän oli siinä, ei hänen oikeasta peliurastaan. Roenick on itse jäsentänyt pelistä saamansa palautteen ("ja saan sitä joka toinen päivä joko Twitterissä tai kadulla") kolmeen seikkaan: 1) "Chicago Blackhawksin voittaminen NHL 94:ssä on mahdotonta Jeremy Roenickin takia"; 2) "Suoritin collegen pelaamalla Jeremy Roenickilla'94 Segalla"; 3) "Blackhawkseilla ei saanut pelata, koska sitä ei voinut pysäyttää". (Sit. Norman 2013; ks. myös Satriano ja O'Leary 2018.)

Hän toteaa tiedostavansa, että hänestä on osin Swingers-elokuvan takia tullut osa popkulttuuria, ja että se on pitänyt hänet yleisön tietoisuudessa. Hänestä on tullut yksi suurimmista urheiluvideopelihahmoista Pohjois-Amerikassa, mikä johti hänen esiintymiseensä pelien kannessa vielä 2000-luvun alkuvuosina. Roenick myönsi, että ympäri maailmaa myytävän pelin kanteen pääseminen on poikkeuksellinen kunnia, sillä se tavoittaa niin monta demografista joukkoa ja saa pelaajan näyttämään poikkeukselliselta. Kun häneltä kysyttiin, koettivatko hänen joukkuetoverinsa kuittailla hänelle kansikuvista, hän totesi ironisesti, että jotkut yrittivät, mutta hän vain näytti niissä aivan liian hyvältä, että se olisi kantanut mihinkään. ${ }^{9}$ (Barry 2018.) Viime kädessä on kuitenkin kyse siitä, että hän on ymmärtänyt, että hänen myyttinen maineensa perustuu NHL 94 -pelihahmolle, ja hän selvästi myös nauttii tästä ristiriitaisesta asemastaan ex-huippuammattijääkiekkoilijana.

\footnotetext{
${ }^{9}$ Roenick tunnettiin itsevarmana ja mediassa viihtyvänä tähtenä, joka piti provosoinnista. Kun hän yritti ärsyttää maalivahti Patrick Roy'ta median kautta, Roy totesi, ettei kuule Roenickia, koska hän on tunkenut Stanley Cup -sormukset korviinsa. Royn vastaus oli piikki siitä, että Roenick ei koskaan voittanut NHL:n mestaruutta.
} 
Kanadalainen urheilukanava TSN teki humoristisen muka-haastattelun Roenickin paljastuksesta koskien ihmisten mielenkiintoa häneen. Roenick kysyy jo ennen ensimmäistä haastattelijan kysymystä, "ethän vain aio kysyä NHL 94:stä?" Toimittaja on hätkähtävinään, ja kamera tarkentaa tämän kysymyspaperiin: kaikki kysymykset koskevat peliä ja ovat lähinnä korneja ("mikä on suosikkivuorokaudenaikasi pelata NHL 94:ää?") tai provosoivia ("miten oikea Roenick pärjää vertailussa pelin Roenickille?"). Roenick alkaa selittää turhautuneena, että hän pelasi USA:n maajoukkueessa, teki NHL:ssä 500 maalia (mihin on pystynyt vain 45 pelaajaa liigan historiassa) ja kehottaa lukemaan kirjansa (jota hän näyttää kameralle), jos ihmiset ovat hänestä kiinnostuneita, mutta pelistä hän ei ole kiinnostunut puhumaan. (TSN 2015.) Peli on tehnyt Roenickista paljon kuuluisamman kuin mitä hän olisi pelaajana ollut, ja hän on tästä tietoinen. Pelin tuoma huomio sekä imartelee häntä että hämärtää hänen saavutuksiaan huippupelaajana, sillä hän ei hahmonsa tapaan ollut kuitenkaan ylivertainen pelaaja," paras".

Mistä Roenickin hahmon ylivertaisuus pelissä sitten johtuu? NHL 94:n tuottaja Michael Brooks rinnastaa mielenkiintoisella tavalla pelihahmon ja biologisen ihmisen: "Roenick oli tilastollisen viriiliyden täydellinen näytekappale. Jos näkisit hänen tilastonsa spermapankissa, haluaisit hänen ominaisuutensa" (sit. Johnson 2013). Brooks tarkoittanee sanalla "stat" ensi sijassa (mitattavia) ominaisuuksia, mutta jää hieman epäselväksi, puhuuko hän ihmis-Roenickista, pelihahmo-Roenickista vai molemmista. Johnson (ibid.) sen sijaan tekee eron pelihahmo-Roenickin ja tämän tosielämän esikuvan välillä toteamalla, että viimeksi mainittu oli "loistava, mutta ei niin loistava [kuin NHL 94 -pelissä]; todellisuudessa hän ei todennäköisesti mahtuisi unelmajoukkueeseesi, mutta pelihahmona hän on ensimmäinen valintasi. Jostain syystä taidot, jotka tekevät urheilijasta todella muistettavan ovat eri taitoja, kuin jotka tekevät virtuaaliurheilijasta loistavan".

Brooks nostaa esiin parhaan mahdollisen esimerkin, kun puhutaan tuon aikakauden jääkiekosta, eli Wayne Gretzkyn. Siinä missä pelaajahahmolle on helppo asettaa nopeus ja laukaisutarkkuus, pelisilmä ja -vaisto ovat paljon hankalampia mallintaa. Gretzkylle nämä asetettiin korkeammalle kuin muille pelaajahahmoille NHL 94 -pelissä, mutta "hyvä intuitio" ei merkitse paljoakaan kolmen erän jääkiekkopelissä erityisesti silloin, kun ihmispelaaja ottaa hahmon hallintaansa ohjelmoidulta tietokonepelaajalta. ${ }^{10}$ Gretzkyn ilmiömäinen taidokkuus "haihtuu ilmaan", "marginalisoituu", koska pelaajan "tietoisuus" ei todennäköisesti ole yhtä hyvä kuin Gretzkyn. (Sit. Johnson 2013.)

Lausunto on samaan aikaan rehellinen ja röyhkeä, sillä harva ammattilaisjääkiekkoilija kehtaisi väittää omaavansa saman pelisilmän ja pelinlukutaidon kuin Gretzky, mutta tuottaja Brooks näyttää väittävän, että se on onnistuttu luomaan tämän pelaajahahmoon NHL 94 -pelissä. Väite on nähtävä enemmän markkinointikikkana kuin vakavasti harkittavana asiana, sillä on mahdoton kuvitella, miten pelin ohjelmoijat kykenisivät vangitsemaan Gretzkyn kaltaisen poikkeuksellisen urheilijan "vaiston" periaatteessa varsin yksinkertaiseen pelimoottoriin. ${ }^{11}$ Niinpä hänen tietyt attribuuttinsa - keskinkertainen nopeus ja fyysisen kamppailuvoiman puute - määrittivät häntä enemmän pelissä kuin hänen suurimmat vahvuutensa. Pelihahmo jäi helposti nopeampien ja vahvempien jalkoihin. Sen sijaan Roenickin

10 Pelissä pelaajalla on automaattisesti ohjauksessaan (vain) se pelihahmo, jolla on kiekko hallussaan. Jos kiekko on vastustajalla, pelaaja voi vaihdella vapaasti pelaajaa, jota kulloisellakin hetkellä ohjaa.

11 "Taidon" ja reaktionopeuden kaltaisten pelielementtien on epäilty rajoittavan esimerkiksi iäkkäämpien pelaajien urheilupelipelaamista, osin siitä syystä, että oman ikäisiä vastustajia on vaikea löytää online-monipelaajapeleihin (Quand et al. 2014, 38). 
hahmon ominaisuudet olivat kenen tahansa peliä edes hieman taitaneen käsissä erittäin käyttökelpoisia. (Johnson 2013.) ${ }^{12}$

\section{Samastuminen jääkiekkopelissä}

Oli aika hienoa. Tällä kaudella olen pelannut NHL 19 -peliä sen kanssa, niin oli hienoa päästä pelaamaan sitä vastaan täälläkin. Niissä olen ollut aika kova, en tiedä olenko ihan niin kova kuin nyt kunnolla pelatessa, mutta ihan hyvä niissäkin. (Sit. Paasi 2019.)

Näin kuvaili odotuksiaan kevään 2019 jääkiekon maailmanmestaruuskisojen aikana Suomen joukkueen nuori tähti Kaapo Kakko (s. 2001). Hän puhui Suomen juuri päättyneestä ottelusta Yhdysvaltoja vastaan. "Se", jota vastaan Kakko erityisesti oli odottanut päästä pelaamaan, oli USA:n tähtihyökkääjä Patrick Kane (s. 1988). Hän toteaa pelanneensa Kanea vastaan huippusuositussa digitaalisessa jääkiekkopelissä NHL 19, mutta lausunnon tarkka merkitys jää avoimeksi: onko hän siis todella pelannut internetin palvelimella NHL-tähti Kanea vastaan, vai ainoastaan peliin luotua virtuaalista Kanea vastaan, kuten joissain samasta haastattelusta tehdyissä toisissa mediajutuissa tulkittiin (ks. esim. Miettinen 2019)? Vai tarkoittaako "sen kanssa", että Kakko on pelannut NHL 19 -peliä pelihahmo Kanella, ja nyt oikeasti häntä vastaan kaukalossa. Itse asiassa tämä merkitysten häilyvyys tuo urheilupeleihin mielenkiintoisen, pelihahmoon samastumiseen liittyvän ulottuvuuden.

Kakosta on nyt pelihahmo tuoreessa NHL 20 -pelissä ja näin hänelle on mahdollista päästä pelaamaan jonkun toisen näkemyksellä siitä, millainen pelaaja hän on. ${ }^{13}$ Myös Roenick on myöntänyt pelanneensa poikansa kanssa NHL-pelejä "itsenään" (siis pelihahmo Roenickina), mutta toteaa, ettei osaa nuoruuden videopeli-innostuksestaan huolimatta pelata kiekkopelejä, koska ei ole ehtinyt niihin perehtyä paremmin. Hänen poikansa on sen sijaan pelannut enemmän, myös isänsä hahmolla. (Barry 2018.) Tässä tulee hyvin esiin eri ammattikiekkoilijasukupolvien ero, vaikka edellä kävikin ilmi, että myös Kakkoa huomattavasti vanhemmat nykypelaajaikäluokat ovat NHL-pelejä pelanneet.

NHL 94 teki varmasti monista, varsinkin Pohjois-Amerikassa, Chicago Blackhawks- ja Roenick -faneja, vaikka nämä eivät välttämättä edes seuranneet jääkiekkoa ennen peliin hurahtamista. Roenickista se, että peleissä alettiin käyttää "oikeita" (haastattelijan muotoilu) pelaajia oli hyvä idea, sillä se auttoi (oikeita) pelaajia saamaan näkyvyyttä ja tunnistettavuutta. ${ }^{14}$ (Sit. Barry 2018.) Pelissä otteluiden alussa esiintynyt (tietokoneanimoitu) selostaja ${ }^{15}$ Ron Barr kertoi Roenickin tapaan, että ihmiset - usein lapset - tunnistivat hänet ja kysyivät, että etkö sinä olekin se tyyppi siitä jääkiekkopelistä (Pinchevsky 2013). Tämä osoittaa jälleen, miten urheilupelin

\footnotetext{
12 Pelin tunnettuja erikoisuuksia, joka hyödytti nimenomaan Roenickiakin, oli se, että pelaajan painolla on päinvastainen vaikutus kuin todellisuudessa. Roenickin kaltainen kevyempi - pienempi ja nopeampi - pelaaja saattoi jyrätä isommat jalkoihinsa. (Satriano ja O'Leary 2018.) Kyseessä oli ilmeisesti tahaton piirre, sillä se korjattiin seuraaviin peleihin.

13 Kakon pelihahmo on nähtävissä täällä: https://www.suomikiekko.com/2019/08/nain-kaapo-kakontaidot-on-arvioitu-pian-julkaistavassa-nhl-20-pelissa/. Linkki tarkistettu 11.11.2019.

14 Roenick on sittemmin avustanut EA Sportsia myöhemmissä peleissä, muun muassa animoinnissa käytettävissä liikkeenkaappauspuvuissa esiintyen, mukaan lukien Tiger Woods -golfpelissä (golf on ammattilaisjääkiekkoilijoiden suosikkiharrastuksia). (Barry 2013.)

15 NHL 98 -pelin suomalaispainoksessa oli jopa kiekkopiireissä suuresti arvostetun "paikallisselostajan" J.P. Jalon selostus (TPS, myöhemmin Jokerit), mikä nostettiin pelin suomiedition takakannessa näkyvästi esiin.
} 
ja laajemman jääkiekkokulttuurin välinen suhde on kaksisuuntainen ja moniselitteinen. Parhaiten tämä tulee kuitenkin esiin kysymyksessä pelaajiin samastumisesta.

Lehtonen kertoo edellä mainitussa Pelaajan jutussaan, että "(e)mme olleet innostuksemme kanssa yksin, sillä Turussa pyöri noihin aikoihin useita NHL 94 -liigoja, joissa pelaajat valitsivat kukin itselleen joukkueen ja sitten pelasivat sarjoja niiden kanssa. Peli itse ei moista tukenut, vaan kirjanpito hoidettiin käsin. Jokaisen pelin jälkeen pistemiehet ja tulokset kirjattiin ylös ja kauden lopuksi pelattiin oikein pudotuspelit." Hän päättää hyvin mielenkiintoiseen näkökohtaan: "Se, että NHL 94 on edelleen minulle kaikkien aikojen suosikkikiekkopelini, johtuu varmasti enimmäkseen näistä pelin ulkopuolisista asioista. [kursiivi R.M.] Mutta ei fanitus yksin siitä johdu. NHL 94:ssä yhdistyivät 16-bittisten aikojen urheilupelien sujuvuus ja helppous aikanaan riittävään realismiin ja tuloksena oli puhdasta kiekkomagiaa." (Lehtonen 2018.) Peli, jääkiekko ja lajikulttuurit sekoittuvat keskenään.

Urheilupelin pelaajan ja pelihahmon välisen suhteen häilyvyys, johon Kakon kertomuksen tulkintojen kohdalla viittasin, käy hyvin ilmi seuraavassa kuvauksessa retropelitapahtumasta. Pelinä on NHL 94, pelaajien valitsemat joukkueet ovat Philadelphia Flyers (pelaaja: Insanolord) ja New York Rangers (pelaaja: kirjoittaja, eli jutun 'minä'). Alla pelaajien yhteenveto ottelusta, kaikki kursiivit ovat minun lisäämiäni:

Ensimmäinen erä oli minulle kivikkoinen. Minulla oli vaikeuksia merkata Phillyn [Philadelphia] isoja tähtiä enkä puolustanut hyvin, joka johti Insanolordin tekemiin maaleihin. Hän käytti Eric Lindrosia tekemään kaksi maalia ja Mark Recchi teki kolmannen vain 13 sekuntia ennen erän loppua. Tilanne näytti jo synkältä, mutta sitten annoin kiekon Brian Leechille [...] ja minä pääsin tulostaululle vain kaksi sekuntia ennen erän loppua.

Toinen erä oli vähemmän tapahtumarikas [...] mutta onnistuin pääsemään tulostaululle Mark Messierillä tehdessäni 3-2-maalin. [...] Onnistuin pitämään Insanolordin poissa tulostaululta loppuerän, raapien itseni takaisin peliin.

Kolmas erä oli EEPPINEN. Insanolord yritti epätoivoisesti syöttää Eric Lindrosille, jotta tämä viimeistelisi minut (harmi vain, ettei Lindros kestä taklaamista yhtään), ${ }_{1}^{16}$ kun minä taas vain yritin tasoittaa pelin. Lauoin tolppaan, kun peliä oli jäljellä 6:40 [...]. Peli pääsi vauhtiin kunnolla, kun Insanolord käytti vahingossa maalivahtiaan antamaan kiekon Messierille aivan maalin lähellä, ja minä tein tasoitusmaalin tyhjiin, kun peliä oli jäljellä 3:11. Nyt meille alkoi kerääntyä yleisöä, ja asiat alkoivat muuttua MIELENKIINTOISIKSI.

Seuraavat muutamat minuutit täyttyivät molempien puolien muutamista hurjista taklauksista. Kumpikaan meistä ei antanut tuumaakaan periksi, kunnes otin kontrollin Mike Gartnerista (numero 22, eli "The Gartner Snake"), pelasin vapaaksi Rod Brind'Amourin (numero 17) ja luistelin Philadelphian alueelle. Harhautin vastustajan maalivahdin klassisella siksak-liikkeellä ja tein KAUNIIN maalin Phillyn maalin yläkulmaan päästen 4-3-johtoon, kun peliä oli jäljellä vain 32 sekuntia! Yleisöstä kuului hurrauksia, ja Insanolord läimäytti pöytää turhautuneena!

Epäonnekseni hänen läimäyksensä muutti urheiluhistorian kulkua. Peli nimittäin jämähti iskun seurauksena, ja kuva juhlivista Rangers-pelaajistani tallentui ikimuistoisesti TV-ruudulle. Emme saa koskaan tietään, miten nuo 32 sekuntia olisivat menneet, mutta pysyn luottavaisena, että Messier ja Rangersit olisivat hallinneet voitokkaina loppuun asti.

(Lindemann 2010.)

\footnotetext{
${ }^{16}$ Isokokoisen, häikäilemättömän ja erittäin taitavan Lindrosin uraa varjostivat ja sen lopulta päättivät (tosin vasta paljon NHL 94 -pelin jälkeen) rajuista taklauksista tulleet aivotärähdykset, joita hän sai kahdeksan kappaletta vuosina 1998-2004. Tässä pelaaja siis lukee "taaksepäin" Lindrosin historiaa.
} 
Välillä kertoja on "minä", seuraavaksi hän "ottaa kontrollin Gartnerista" ja "pelaa vapaaksi Brind'Amourin", joksi hän muuttuu kiekon saatuaan: "harhautin maalivahdin". Hän "antaa kiekon" Leechille, jonka avulla hän "pääsee tulostaululle" (eli syntyy maali). Vastustaja (Insanolord) taas "käyttää Lindrosia" tekemään maaleja ja toisessa kohtaa "yrittää epätoivoisesti syöttää" tälle. Kertomuksen lopuksi Messier ja muut ovat "hänen Rangers-pelaajiaan", jotka olisivat todennäköisesti "hallinneet loppuun asti". Peli - eli lopussa mukaan tuleva uusi subjekti pelaajien ja pelihahmojen ohella - kuitenkin jäätyi, ehkä Insanolordin turhautuneen pöydän läimäytyksen takia. Pelaajan identifikaatio selvästi vaihtelee pelin sisällä: hän on pelaajana "oma itsensä" yhtenä hetkenä, joka ohjaa pelin ulkopuolisena pelihahmoja, mutta toisena hän antaa kiekon pelihahmolle, joka tekee maalin, jonka ansiosta pelaajalle kirjataan maali. Hän syöttää pelaajahahmolle ja muuttuu täksi kiekon haltuun saadessaan. Samastuminen on reaaliaikaisesti syntyvää, jatkuvassa muutosten ketjussa.

\section{Lopuksi}

NHL-pelien ja samanlaisten tosielämän vastineille perustuvien urheilupelien samastuminen on monitasoista. Pelaaja voi ihailla ja pelin kautta samastua urheilijaan tai yleisemmin suosikkiseuraansa. Pelin kautta samastuminen vahvistuu, sillä pelaaja pelaa suosikkiseuransa menestystä tavoitellen - NHL-peleissä tämä tarkoittaa Stanley Cupin, eli NHL:n mestaruuden, voittamista peliin rakennetun runkosarjaplay-off-moottorin avulla. Toisaalta pelin kautta voi alkaa pitää tai arvostaa uudella tavalla jotain peliin luodusta virtuaalipelaajasta. Muistan tästä itsekin esimerkkejä 1990-luvulta, jolloin pelejä kaverien kanssa pelasin. Joku saattoi tehdä paljon maaleja pelin pelaajalla N.N., joka johti ajattelemaan, että tämän on pakko olla poikkeuksellisen hyvä pelaaja myös todellisuudessa. Monta kertaa kuitenkin tilastoja tarkistelemalla paljastui, että kyseinen pelaaja ei todellisuudessa ollut samanlainen otteluita videopelissä maaleillaan ratkonut kärkipelaaja, vaan niin sanottu pienten minuuttien rivimies. Jostain syystä kyseisen pelaajan pelihahmo sattui vain sopimaan videopelaajan "käteen".

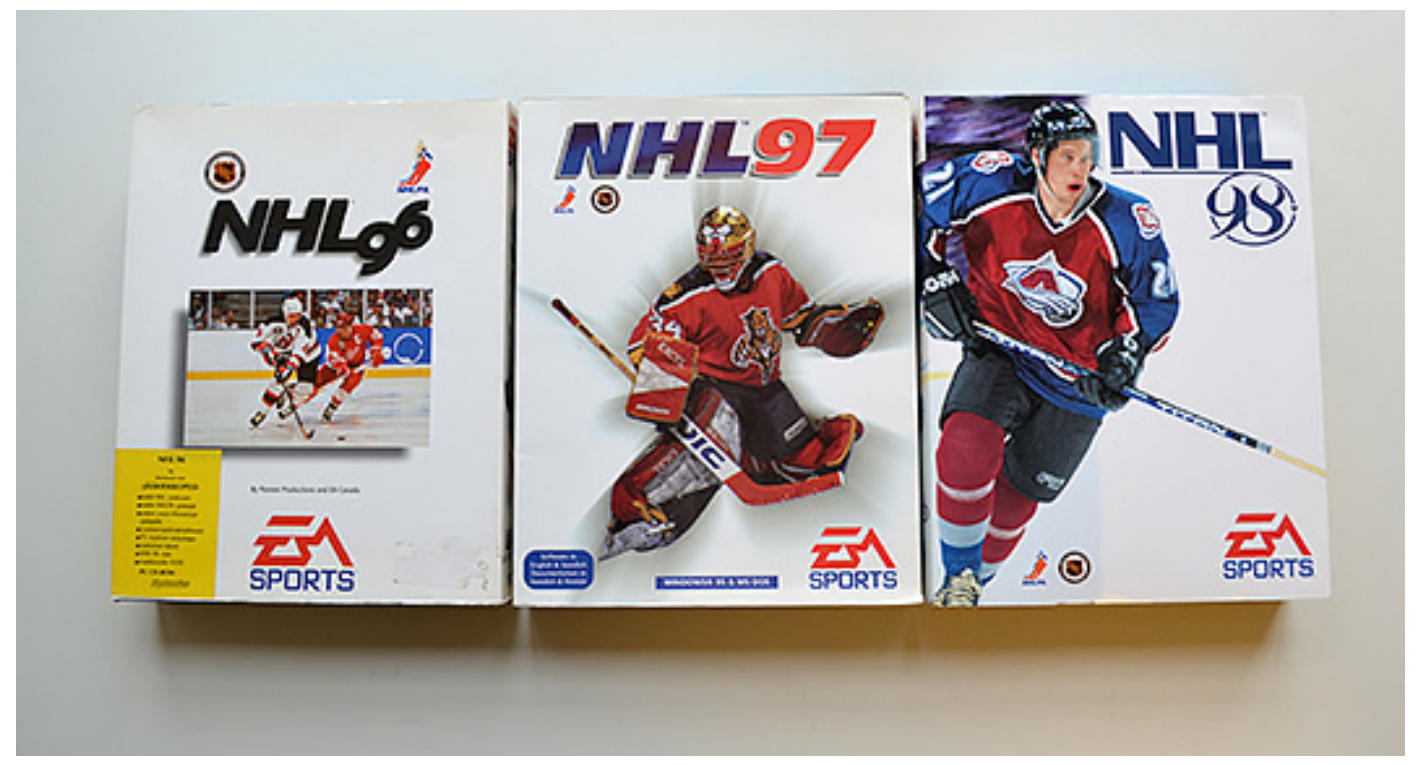

Electronic Arts on julkaissut NHL-pelejä vuosittain vuodesta 1991 alkaen eri pelikonsoleille sekä PC:lle. Kuva: Rami Mähkä. 
Edellä siteeratun Johnsonin (2013) tavoin Good (2008) kutsuu Roenickia "yhdeksi viimeisistä urheilupelijumalista". Perusteluna hänellä on se, että vaikka urheilupelisuunnittelijat hiovat pelien realismia asteittain yhä täydellisemmäksi, on yhä mahdollista pelata "aikamme parhaina [urheilijoina]". Kuitenkaan heidän [sic] suorituksensa eivät dominoi pelitapahtumia ruudulla kuten Roenick teki NHL 94:ssä. Hänen lahjakkuutensa [sic] oli niin puhdasta, hehkuvan kuumaa ja kestävää, ja se asetti hänet ja hänen pelinsä [ensisijainen merkitys "pelitapa", toissijainen NHL 94] yhteen kulttiklassikon muistettavimmista kohtauksista. Good viittaa viimeksi mainitulla Swingers-elokuvaan.

Swingersin kohtauksesta tehtiin myöhemmin parodia ("Swingers Hockey with Jeremy Roenick", 2011), jossa Roenick esittää Kings-fania. Vaughnin paikalla on puolestaan urheilutelevisiotuottaja Bernie Kim, joka tekee välittömästi "Roenickilla" maalin. Oikea Roenick syyttää Kimiä huijaamisesta "Blackhawkseilla", koska "Roenick on liian hyvä, hän on paras!" Vaivaantunutta esittävä Kim kehottaa Roenickia jatkamaan pelaamista. Roenick jatkaa: "Hän on niin komea, ja mikä ihmisystävä...", mutta palaa sitten alkuperäisen elokuvakohtauksen dialogiin.

Roenick on todennut kysyttäessä, että hänen maineensa ei perustu sille, että hän olisi ollut todellisuudessa yhtä hyvä pelaaja kuin pelihahmo Roenick, mutta toisaalta hänen poikkeuksellinen maineensa tulee siitä, että hän oli paras "video hockey guy in video game history". Virtuaaliurheilupelien ja kasvavan e-urheilun aikakaudella saavutus on huomattava ja se herättää kysymyksiä, joihin vastaaminen vaatii systemaattista tutkimusta. Tämän artikkelin tarkoituksena oli kartoittaa tutkimusaihetta yhden historiallisen esimerkin avulla.

\section{Lähteet}

Barry, Sal (2018) Interview: Jeremy Roenick on NHL '94. Puck Junk 25.10.2019. Saatavilla: <https:// puckjunk.com/2018/10/25/interview-jeremy-roenick-on-nhl-94/> (linkki tarkistettu 8.11.2019).

Classic Gaming Quarterly (2016) The History of NHL ‘94. Classic Gaming Quarterly 4.2.2019. Saatavilla: $<$ https://www.youtube.com/watch?v=PiiOgGAMiEQ> (linkki tarkistettu 11.11.2019).

Good, Owen (2009) A Tribute to One of the Last Sports Game Gods. Kotaku 8.8.2009. Saatavilla: <https:// kotaku.com/457583529> (linkki tarkistettu 10.11.2019).

Graham, John Wallace (2013) An Ode to the Best Game Ever. The Hockey Writers 20.7.2013. Saatavilla: $<$ https://thehockeywriters.com/an-ode-to-nhl-94-the-best-game-ever/> (linkki tarkistettu 8.11.2019).

Gray, Jonathan (2010) Sold Separately: Promos, Spoilers, and Other Media Paratexts. New York: New York University Press.

Hockey Beast (2019) “Jeremy Roenick was a beast in NHL 94". Hockey Beast 14.8.2019. Saatavilla: <https://www.facebook.com/1638998306322761/posts/2352217051667546/> (linkki tarkistettu 6.9.2019).

Jenkins, Henry (2006) Convergence Culture: Where Old and New Media Collide. New York: New York University Press.

Johnson, Jason (2013) We talk to NHL'94's producer to figure out why the game is still revered today. Killscreen 30.9.2013. Saatavilla: <https://killscreen.com/articles/we-talk-nhl-94s-producer-figure-outwhy-game-still-revered-today/> (linkki tarkistettu 5.9.2019).

Kim, Yongjae \& Roos, Stephen (2006). An exploration of motives in sport video gaming. International Journal of Sports marketing and Sponsorship 8:1, 28-40.

"King of 94" (2019). Saatavilla:<https://smash.gg/tournament/king-of-94-4-toronto> (linkki tarkistettu 5.9.2019).

Kinnunen, Jani; Lilja, Pekka \& Mäyrä, Frans (2018) Pelaajabarometri 2018: Monimuotoistuva mobiilipelaaminen. Tampere: Tampereen yliopisto. Saatavilla: <http://urn.fi/URN:ISBN:978-952-03-0870-4> (linkki tarkistettu 6.11.2019). 
Lehtonen, Miikka (2018) Retrostelussa NHL94 - kaikkien aikojen legendaarisin retropeli. Pelaaja.fi 12.5.2018. Saatavilla: <https://pelaaja.fi/artikkelit/retrostelussa-nhl-94-kaikkien-aikojen-legendaarisinlatkapeli> (linkki tarkistettu 5.9.2019).

Lindemann, Jon (2010) PAX East 2010 Reader Challenge: NHL'94. Nintendo World Report 3.4.2010. Saatavilla: <http://www.nintendoworldreport.com/feature/22839/pax-east-2010-reader-challenge-nhl-94> (linkki tarkistettu 10.11.2019).

McCrea, Nick (2015) Retired developer who created 'NHL '94' video game in Maine barn reflects on career. Bangor Daily News 21.2.2015. Saatavilla: <https://bangordailynews.com/2015/02/21/living/ retired-developer-who-created-nhl-94-video-game-in-maine-barn-reflects-on-career/> (linkki tarkistettu 6.9.2019).

Miettinen, Heikki (2019) Kaapo Kakko kohtasi idolinsa, joka on tuttu NHL 19 -pelistä: "Oli hienoa päästä pelaamaan häntä vastaan". Helsingin sanomat 13.5.2019. Saatavilla: <https://www.hs.fi/urheilu/ art-2000006104492.html> (linkki tarkistettu 14.11.2019).

NHL (2013) Looking Back: 20 th Anniversary of EA NHL'94. NHL YouTube 20.3.2013. Saatavilla: <https:// www.youtube.com/watch?v=spd3k6Yx5FI> (linkki tarkistettu 6.9.2019).

Norman, Mark David (2018) NHL '94 and Hockey Nostalgia: An Analysis of Hockey's Most Culturally Resonant Game. Hockey in Society 10.9.2013. Saatavilla: <https://hockeyinsociety.com/2013/09/10/ nhl-94-and-hockey-nostalgia-an-analysis-of-hockeys-most-culturally-resonant-video-game/> (linkki tarkistettu 10.11.2019).

Paasi, Jussi (2019) Kaapo Kakko sai yleisön villiintymään - pelin jälkeen hän nauratti toimittajia: "No nyt saatiin eka kysymys tuosta, hieno homma!" Yle Urheilu 13.5.2019. Saatavilla: <https://yle.fi/urheilu/3-10781407> (linkki tarkistettu 14.11.2019).

Pinchevsky, Tal (2013) EA's NHL '94 remains landmark game after 20 years. NHL.com. Saatavilla: <https://www.nhl.com/news/eas-nhl-94-remains-landmark-game-after-20-years/c-660713> (linkki tarkistettu 8.11.2019).

Quand, Thorsten; Chen, Vivian; Mäyrä, Frans \& Van Looy, Jan (2014) (Multiplayer) Gaming Around the Globe? A Comparison of Gamer Surveys in Four Countries. Teoksessa Thorsten Qaundt \& Sonja Kröger (toim.) Multiplayer: The Social Aspects of Digital Gaming. Lontoo ja New York: Routledge, 23-46.

Satriano, David ja O’Leary, Daniel (2018) ‘NHL ‘94' Video Game Has Enduring Popularity 25 Years Later. NHL.com. Saatavilla: <https://www.nhl.com/news/nhl-94-enduring-popularity-25-yearslater/c-301326816> (linkki tarkistettu 10.11.2019).

“Swingers (1996) Hockey Clip" (2006). Youtube. Saatavilla: <https://www.youtube.com/ watch?v=Z3vHbOilhpc $>$ (linkki tarkistettu 5.9.2019).

"Swingers Hockey with Jeremy Roenick" (2011). Youtube. Saatavilla: <https://www.youtube.com/ watch?v=z1PWACWz1gU> (linkki tarkistettu 5.9.2019).

TSN (2015) Jeremy Roenick VS. NHL '94. TSN 24.11.2015. Saatavilla: <https://www.youtube.com/ watch?v=uleibWrBT70> (linkki tarkistettu 11.11.2019). 